\title{
Educative Doll Design as Media for Learning Indonesian Traditional Folk Song Using Affective Design Approach
}

\author{
H. Soewardi and S. B. Maulidyawati
}

\begin{abstract}
Over the past decade, modernity has become a mainstream factor of entertainment. Unfortunately, it makes traditional things be abandoned slowly, especially in Indonesia. However, the lack of traditional products that can attract users' attention is influenced by the designs from the manufacturers. Thus, the objective of this research is to develop an innovative education doll as media of learning Indonesian folk songs. Kansei Engineering (KE) method and Fuzzy Linguistics principle were used to design. More than 100 respondents were involved in this study to identify the Kansei words. This is because these methods support emotional response of the users in affective design approach. Potential attributes in developing a new single concept design were analysed using Orthogonal array and conjoint analysis. Then, the data were analysed using statistical analysis. This study resulted in an innovative education doll that is proven to be valid in meeting the consumers' requirement.
\end{abstract}

Index Terms-Educative doll design, Indonesian traditional folk song, affective design, kansei engineering, fuzzy linguistic.

\section{INTRODUCTION}

Indonesia is a country that has various kinds of local wisdom. This country consists of 34 provinces where each of these has various ethnic groups that spread from Sabang to Merauke. Each ethnic has its own customs and special cultures that become its identity, especially in the field of art. According to [1], Indonesia possesses various beliefs, cultures, and arts. Thus, it is known as one of the world's richest nations in a diversity of culture.

One of the typical cultures owned by Indonesia is traditional folk song. [2] stated that traditional folk song is heavily correlated to the moral of human being, environment, and a spiritual life. It shows a harmonization between human's characteristic and culture. Therefore, it is significant to deeply comprehend culture so as the course to emerge enthusiasm of people becoming self-characteristic. Unfortunately, based on the preliminary study, it is known that more than $50 \%$ of young people, including children, do not know how to sing traditional folk songs. Worse, approximately $80 \%$ were found to have preference of singing modern songs.

In accordance with the Constitutions of the Republic of Indonesia No. 20 of 2003 article 37 paragraph 1, it is stated that cultural art is one of the compulsory subjects for elementary and secondary students [3]. Thus, this subject, such as traditional folk song, is taught in each school level

\footnotetext{
Manuscript received May 14, 2018; revised July 1, 2018.

The authors are with Faculty of Industrial Technology, Islamic University of Indonesia, Indonesia (e-mail: hartomo@uii.ac.id, sitibarirohm@gmail.com).
}

using standard teaching-learning method. On the other hand, preliminary study identified that the method is not interesting for students, for example they find it difficult to memorize the folk songs. Consequently, it is critical to design new educative media that could facilitate the process of teaching and learning the traditional folk songs. In factm this study is similar with a study of [4]-[6].

Several previous researches on teaching-learning media for children were conducted. They are [7]-[12]. [7] and [9] proposed a scenario of human robot interaction as teaching mediator for children. Meanwhile, [8] developed a digital story telling for remedial students. In addition, [10] and [11] evaluated the effect of puppet as educative media to children. [12] designed teaching media for English learning using lexical coverage of popular songs.

In fact, there are many methods for developing educative media that have been used in several previous researches. For examples, Theory of Inventive Problem Solving (TRIZ), Affective Engineering method, KE method. TRIZ method was used by [13] to design educative toy to stimulate the growth of fine motor skills for disabled children. Affective Engineering by [8] was to design digital story telling for remedial students. [14] used KE type 1 to design board game of integral number arithmetic operation for elementary school.

The objective of this study is to develop an educative doll as media for learning Indonesia's traditional folk song that satisfies users' criteria by using KE type 2 and fuzzy linguistic principle.

\section{RESEARCH METHOD}

\section{A. Survey}

The survey was conducted to identify Kansei words which defined customers' feeling and to validate the developed product by distributing more than 100 questionnaires to children aged 7-12 years old for the first survey. As for the second survey, the questionnaires were distributed to 40 respondents who had similar characteristics.

\section{B. Apparatus}

In this study, some instrumentation were used. They are:

1) Questionnaires were developed consisting of two parts. They are Semantic Differentiation (SD) questionnaires to identify the Kansei words and questionnaires to validate the proposed design.

2) IBM SPSS 20 was used to help the process of data collection, including validity and reliability test, $\mathrm{KMO}$ analysis and conjoint analysis.

3) Corel Draw and Sketchup Pro 2017 software were 
used to develop the virtual design of doll.

4) MATLAB software version R2013a was used to implement the fuzzy model.

\section{Develops the Parameter of Doll Design}

$\mathrm{KE}$ is a technology that merges Kansei into engineering discipline in order to create products that match consumer's needs and desire [15]. The framework developed translates customer's feeling and emotion into design specifications of product [16], [17]. This study used KE type 2.

\section{1) Develops the parameter of doll design}

In KE type 2, the process of translation was conducted from the consumers' Kansei database into product design element database through computer technology (see Fig. 1). This method consisted of two translation systems namely forward and backward. Fig. 2 below describes forward Kansei engineering system [18], [19].

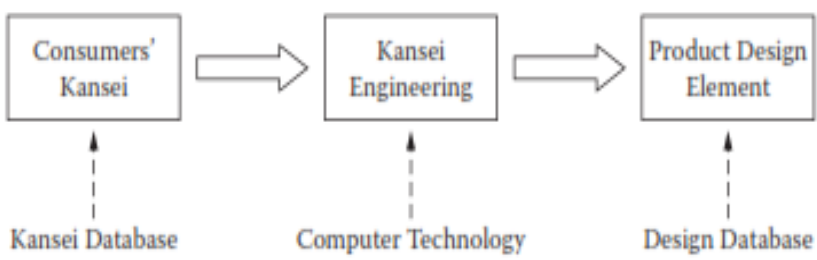

Fig. 1. Translation process of KE type 2 [9].

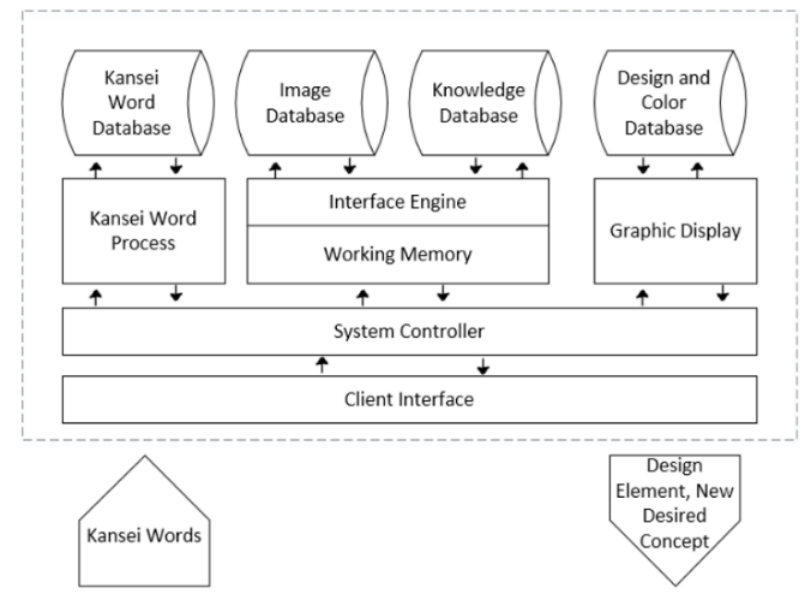

Fig. 2. KE system forward [9].

Several steps on data processing in KE type 2 are performed as follow [19]:

1) Determining the objective of the study.

2) Collecting consumers' need and feeling to obtain the Kansei words.

3) Evaluating the Kansei words using SD 1 with 5 scales.

4) Determining the attributes and elements for the selected Kansei words.

5) Constructing orthogonal arrays and conjoint analysis to make initial virtual design.

6) Evaluating the experiment using SD 2 with 5 scales.

7) Determining the important rating (IR) for each attribute.

8) Making the proposed virtual design based on the result of step 6 and 7.

9) Generating the product mapping concept.

10) Designing final prototype and validating the product.

Fuzzy linguistic is performed to define an ambiguous variable into the fuzzy set meaning [20]. The Kansei preference can be classified using the triangular fuzzy number (TFN) to represent the fuzzy number (see Fig. 3).

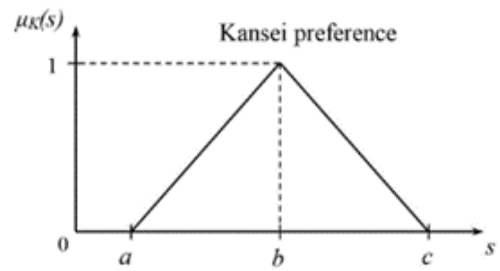

Fig. 3. Kansei preference modeling based on a triangular membership function [21].

Parameters $\mathrm{a}, \mathrm{b}$ and $\mathrm{c}$ depict the smallest possible value, the most promising value, and the largest possible value. They explain the fuzzy events. The membership function is described in formula below.

$$
k(s)=\left\{\begin{array}{l}
\frac{s-a}{b-a}, a \leq s \leq b \\
\frac{s-c}{b-c}, b \leq s \leq c \\
0, \text { otherwise }
\end{array}\right.
$$

\section{2) Statistical analysis}

Cronbach Alpha was used to test the reliability and Spearman's correlation was conducted to test the validity of consumer's preferences of Kansei words [22], [23]. In addition, orthogonal design test was conducted to get the best combination among the proposed attributes based on importance rating score [24].

Statistical Marginal homogeneity test was implemented to validate the hypothesis of the proposed doll design. As for its hypothesis, the attribute of the developed design satisfies customer's Kansei (null hypothesis).

\section{RESULT AND DISCUSSION}

\section{A. Result of Survey}

The survey found nine Kansei words that represented consumers' preferences of the proposed doll design. They are practical, attractive, modern, smooth, Clean, soft and unique.

Practical is related to the doll size which makes it comfortable to carry. Attractive shows that the color of the doll should be bright and interesting. Meanwhile, modern attribute describes that the design is not out of date. In addition, smooth attribute describes that the design is made from velboa material, so that it meets the requirement of being Clean. Finally, the attribute of soft and unique expresses that the design is made from dacron material; besides, it also has attractive shape and interesting motif.

\section{B. Developed Doll Design}

Table I below presents the list of the product attributes and elements that will be used as a reference of design.

In developing doll design, another attribute was not considered since the eight-mentioned attributes were able to 
represent the dominant construction of product. Based on the attributes and elements that have been set up previously, the manufacture of doll design consists of 21 categories with 7 attributes. The selection of minimum sample is obtained by orthogonal array concept.

TABLE I: PRODUCT ATTRIBUTES

\begin{tabular}{|c|c|c|c|c|c|}
\hline Attribute & Elements & Notation & Attribute & Elements & Notation \\
\hline \multirow{3}{*}{ Doll Design } & Human & A11 & \multirow{2}{*}{ Motif } & Plain & A41 \\
\hline & Hand doll & A12 & & Pattern & A42 \\
\hline & Animal & A13 & \multirow{3}{*}{ Size } & Small & A51 \\
\hline \multirow{4}{*}{ Type of Material } & Rasfur & $\mathrm{A} 21$ & & Medium & A52 \\
\hline & Velboa & A22 & & Big & A53 \\
\hline & Nylex & A23 & \multirow{3}{*}{ Material } & Dacron & A61 \\
\hline & Yelvo & A24 & & Plastic pellet & A62 \\
\hline \multirow{3}{*}{ Color } & Light & A31 & & Patchwork & A63 \\
\hline & Medium & $\mathrm{A} 32$ & \multirow{2}{*}{ Technology } & MP3 module & A71 \\
\hline & Dark & A33 & & VR & A72 \\
\hline
\end{tabular}

TABLE II: IMPORTANT RATING AND DETERMINATION ATTRIBUTES

\begin{tabular}{|c|c|c|c|c|c|}
\hline Kansei Words & Selected Attribute & Element Design & IR Score & Constant Value & Description \\
\hline Practical & Size & Moderate & $70.483 \%$ & 3.283 & Fuzzy \\
\hline Attractive & Motif & Motif & $30.605 \%$ & 3.472 & Fuzzy \\
\hline Modern & Voice technology & With program & $56.712 \%$ & 3.439 & Non-Fuzzy \\
\hline Smooth & Outer material & Velboa & $59.637 \%$ & 3.156 & Non-Fuzzy \\
\hline Clean & Color & Bright & $50.626 \%$ & 3.413 & Fuzzy \\
\hline Soft & Inside material & Dacron & $82.869 \%$ & 3.131 & Non-Fuzzy \\
\hline Unique & Design & Human doll & $69.225 \%$ & 3.240 & Fuzzy \\
\hline
\end{tabular}

\section{Fuzzy Linguistic Concept}

From the product attributes, IBM SPSS 22 is used to get initial design combination using orthogonal design function. 32 initial design generated from IBM SPSS 22 will be evaluated based on the largest value of importance rating for each Kansei words. Determination of Kansei words, attributes, element design and IR score will be shown in the table below (see Table II).

Thus, an element with the largest importance rating can be determined have a bigger impact as the main factor in developing the product. Fuzzy linguistics series were performed to represent the important rating for each Kansei words that shown on below (see Table III).

\begin{tabular}{|c|c|c|c|}
\hline \multicolumn{1}{|c|}{ TABLE III: LINGUISTIC SERIES OF KANSEI ATTRIBUTES } \\
Series & Linguistic element & $\begin{array}{c}\text { Fuzzy } \\
\text { Number }\end{array}$ & $\begin{array}{c}\text { Crisp } \\
\text { Number }\end{array}$ \\
\hline $\mathbf{L}$ & $\begin{array}{c}\text { Low Kansei } \\
\text { Preference } \\
\text { Low Importance }\end{array}$ & 1,5 & 3 \\
\hline $\mathbf{M}$ & $\begin{array}{c}\text { Neutral Kansei } \\
\text { Preference } \\
\text { Medium Importance }\end{array}$ & 3,7 & 5 \\
\hline $\mathbf{H}$ & $\begin{array}{c}\text { High Kansei } \\
\text { Preferences } \\
\text { High Importance }\end{array}$ & 5,9 & 7 \\
\hline
\end{tabular}

In this study, triangular fuzzy numbers used to represent the Kansei linguistic variables. In this way, we can establish a linguistic term set for each Kansei attribute, denoted as shown in equation 2 .

$$
\begin{aligned}
& V n=\{V-k n, \ldots, V k n, \ldots, V+k n\} \text { where } \\
& k=-K,-(K-1), \ldots, 0, \ldots .(K-1), K .
\end{aligned}
$$

Example. Assume for the Kansei word of "unique" having left to right side Kansei word \{mediocre, satisfying, unique\} with 3 points scale which similar to linguistic variable, here is the linguistic term:

$\mathrm{V}=\{\mathrm{V}-1, \mathrm{~V}, \mathrm{~V}+1\}=\{$ common, satisfying, unique $\}$

$=\{(-1,0,1),(0,1,2),(1,2,3)\}$

Example. The application of linguistic variable is performed in unique design as described in the table below (see Table IV).

\begin{tabular}{|c|c|c|c|}
\hline \multicolumn{3}{|c|}{ Hair (H) } & \multirow[b]{2}{*}{$\begin{array}{c}\text { Numerical } \\
\text { Range }\end{array}$} \\
\hline $\begin{array}{l}\text { Linguistic } \\
\text { Terms }\end{array}$ & Notation & Description & \\
\hline Tied & $\mathbf{T}$ & The hair of doll is tied & {$[1,3,5]$} \\
\hline Short & $\mathbf{S}$ & $\begin{array}{l}\text { The doll designed with } \\
\text { short hair }\end{array}$ & {$[3,5,7]$} \\
\hline Long & $\mathbf{L}$ & $\begin{array}{c}\text { The doll designed with } \\
\text { long hair }\end{array}$ & {$[5,7,9]$} \\
\hline \multicolumn{4}{|l|}{ Face $(F)$} \\
\hline $\begin{array}{c}\text { Linguistic } \\
\text { Terms }\end{array}$ & Notation & Description & $\begin{array}{c}\text { Numerical } \\
\text { Range }\end{array}$ \\
\hline $\begin{array}{l}\text { Oval } \\
\text { Round } \\
\text { Square }\end{array}$ & $\begin{array}{l}\mathrm{O} \\
\mathrm{R} \\
\mathrm{S}\end{array}$ & $\begin{array}{l}\text { The face with an oval shape } \\
\text { The face with a round shape } \\
\text { The face with square shape }\end{array}$ & $\begin{array}{l}{[1,3,5]} \\
{[3,5,7]} \\
{[5,7,9]}\end{array}$ \\
\hline \multicolumn{4}{|c|}{ Eyes (E) } \\
\hline $\begin{array}{c}\text { Linguistic } \\
\text { Terms }\end{array}$ & Notation & Description & $\begin{array}{c}\text { Numerical } \\
\text { Range }\end{array}$ \\
\hline $\begin{array}{c}\text { Slit } \\
\text { Half-roun } \\
\text { d } \\
\text { Round } \\
\end{array}$ & $\begin{array}{c}\mathrm{S} \\
\mathrm{HR} \\
\mathrm{R}\end{array}$ & $\begin{array}{c}\text { Slit shape eyes } \\
\text { Half-round shape eyes } \\
\text { Round eyes }\end{array}$ & $\begin{array}{l}{[1,3,5]} \\
{[3,5,7]} \\
{[5,7,9]}\end{array}$ \\
\hline \multicolumn{4}{|c|}{ Nose $(\mathbf{N})$} \\
\hline $\begin{array}{c}\text { Linguistic } \\
\text { Terms }\end{array}$ & Notation & Description & $\begin{array}{c}\text { Numerical } \\
\text { Range }\end{array}$ \\
\hline
\end{tabular}

TABLE IV: LINGUISTIC VARIABLE FOR UNIQUE DESIGN 


\begin{tabular}{|c|c|c|c|}
\hline \multicolumn{3}{|c|}{ Hair $(\mathbf{H})$} & \multirow[b]{2}{*}{$\begin{array}{c}\text { Numerica } \\
\text { Range }\end{array}$} \\
\hline $\begin{array}{c}\text { Linguistic } \\
\text { Terms }\end{array}$ & Notation & Description & \\
\hline Tied & $\mathbf{T}$ & The hair of doll is tied & {$[1,3,5]$} \\
\hline Short & $\mathbf{S}$ & $\begin{array}{c}\text { The doll designed with } \\
\text { short hair }\end{array}$ & {$[3,5,7]$} \\
\hline Long & $\mathbf{L}$ & $\begin{array}{c}\text { The doll designed with } \\
\text { long hair }\end{array}$ & {$[5,7,9]$} \\
\hline \multicolumn{4}{|l|}{ Face $(\mathbf{F})$} \\
\hline $\begin{array}{c}\text { Linguistic } \\
\text { Terms }\end{array}$ & Notation & Description & $\begin{array}{c}\text { Numerical } \\
\text { Range }\end{array}$ \\
\hline $\begin{array}{l}\text { n shape } \\
\text { u shape } \\
\text { L shape }\end{array}$ & $\begin{array}{l}\mathrm{n} \\
\mathrm{u} \\
\mathrm{L}\end{array}$ & $\begin{array}{l}\text { The doll with } \mathrm{n} \text { shape nose } \\
\text { The doll with u shape nose } \\
\text { The doll with L shape nose }\end{array}$ & $\begin{array}{l}{[1,3,5]} \\
{[3,5,7]} \\
{[5,7,9]}\end{array}$ \\
\hline \multicolumn{4}{|c|}{ Lips (L) } \\
\hline $\begin{array}{c}\text { Linguistic } \\
\text { Terms }\end{array}$ & Notation & Description & $\begin{array}{c}\text { Numerical } \\
\text { Range }\end{array}$ \\
\hline $\begin{array}{c}\text { Closed } \\
\text { Open smile } \\
\text { Smile }\end{array}$ & $\begin{array}{l}\mathrm{C} \\
\mathrm{O} \\
\mathrm{S}\end{array}$ & $\begin{array}{c}\text { Normal shape lips or a } \\
\text { moustache } \\
\text { Open smile shape lips } \\
\text { Line smile shape lips }\end{array}$ & $\begin{array}{l}{[1,3,5]} \\
{[3,5,7]} \\
{[5,7,9]}\end{array}$ \\
\hline \multicolumn{4}{|l|}{$\begin{array}{l}\text { Unique } \\
\text { Design }\end{array}$} \\
\hline $\begin{array}{c}\text { Linguistic } \\
\text { Terms }\end{array}$ & Notation & Description & $\begin{array}{c}\text { Numerical } \\
\text { Range }\end{array}$ \\
\hline Common & $\mathrm{C}$ & $\begin{array}{c}\text { The design considered as } \\
\text { mediocre }\end{array}$ & {$[1,3,5]$} \\
\hline $\begin{array}{c}\text { Satisfactor } \\
\mathbf{y}\end{array}$ & $S$ & $\begin{array}{l}\text { Design was satisfy the } \\
\text { consumer, but not special }\end{array}$ & {$[3,5,7]$} \\
\hline Unique & $\mathrm{U}$ & The design is unique & {$[5,7,9]$} \\
\hline
\end{tabular}

$\mathrm{H}, \mathrm{W}, \mathrm{E}, \mathrm{N}$, and L. Based on the fuzzy calculation, the best combination for "unique design" is by making sense of centroid fuzzy score 5, 8, 7 and 3 as shown in table below (see Table V).

TABLE V: CENTROID FUZZY FOR UNIQUE

\begin{tabular}{|c|c|c|}
\hline Elements & Optimum Value & Selected Design \\
\hline Hair & 3 & Hair tied \\
Face & 5 & Round shape \\
\hline Eyes & 8 & Round shape \\
\hline Nose & 7 & L shape \\
\hline Lips & 3 & $\begin{array}{c}\text { Normal shape or a } \\
\text { moustache }\end{array}$ \\
\hline
\end{tabular}

Example. Formation of IF .... THEN rules described below:

[1] If ( $\mathrm{H}$ is $\mathrm{T})$ and ( $\mathrm{F}$ is $\mathrm{O})$ and ( $\mathrm{E}$ is $\mathrm{S})$ and $(\mathrm{N}$ is $\mathrm{n})$ and ( $\mathrm{L}$

is $\mathrm{C}$ ) then (design is common) (1)

[2] If ( $\mathrm{H}$ is $\mathrm{S})$ and ( $\mathrm{F}$ is $\mathrm{O})$ and ( $\mathrm{E}$ is $\mathrm{S})$ and $(\mathrm{N}$ is $\mathrm{u})$ and ( $\mathrm{L}$ is $\mathrm{O})$ then (design is satisfying) (1)

[3] If ( $\mathrm{H}$ is $\mathrm{S})$ and ( $\mathrm{F}$ is $\mathrm{R})$ and ( $\mathrm{E}$ is $\mathrm{S})$ and $(\mathrm{N}$ is $\mathrm{n})$ and ( $\mathrm{L}$ is $\mathrm{S})$ then (design is common) (1)

\section{Product Mapping Concept of Product Design}

After the KE and fuzzy linguistic data processing were done, then generate the following product mapping concept as mentioned in the table below (see Table VI).

As the result, weighing the rules of fuzzy to fulfil the "unique design" by finding the optimum value of the variable

\begin{tabular}{|c|c|c|c|c|}
\hline $\begin{array}{l}\text { Kansei } \\
\text { words }\end{array}$ & Description & Sub Concept Level 1 & Sub Concept Level 2 & Design Spesification \\
\hline Practical & $\begin{array}{l}\text { Provide design which } \\
\text { practical or easy to } \\
\text { handle }\end{array}$ & Doll design size & $\begin{array}{l}\text { Height and diameter of } \\
\text { the doll }\end{array}$ & $\begin{array}{c}\text { Height: } 32 . \mathrm{cm} \\
\text { Diameter: } 10.5 \mathrm{~cm}\end{array}$ \\
\hline \multirow[t]{2}{*}{ Attractive } & \multirow{2}{*}{$\begin{array}{l}\text { Attract attention with } \\
\text { the pattern on the doll } \\
\text { clothes }\end{array}$} & Patterned doll clothes & Top side pattern & Top: one motive in the center of the top \\
\hline & & & Bottom side pattern & Bottom: batik pattern \\
\hline Modern & $\begin{array}{l}\text { Provide doll technology } \\
\text { to sing a folk song }\end{array}$ & Source of doll sounds & Programmed & $\begin{array}{l}\text { VR with several button as } \\
\text { command/control }\end{array}$ \\
\hline Smooth & Comfort fabric material & Outside doll looks & Outside material & Velboa \\
\hline \multirow{2}{*}{ Clean } & \multirow{2}{*}{$\begin{array}{l}\text { Depicted with doll's } \\
\text { color that are easy } \\
\text { removed when dirty }\end{array}$} & \multirow{2}{*}{ Doll colors } & Body Color & $\begin{array}{c}\text { Light Yellow } \\
\text { R: } 252 \text { G: } 241 \mathrm{~B}: 177\end{array}$ \\
\hline & & & Shirt Color & $\begin{array}{cc}\text { Red } \\
\text { R: } 252 \text { G: } 95 & \text { B: } 78 \\
\end{array}$ \\
\hline Soft & $\begin{array}{l}\text { Made from material } \\
\text { that comfortable to be } \\
\text { touched }\end{array}$ & Inside doll preference & Inside material & Dacron \\
\hline \multirow{5}{*}{ Unique } & \multirow{5}{*}{$\begin{array}{l}\text { Attractive shape and } \\
\text { design of the doll }\end{array}$} & \multirow{5}{*}{ Head section } & Hair & Hair tied \\
\hline & & & Face & Round face \\
\hline & & & Eyes & Round eyes \\
\hline & & & Nose & L shape \\
\hline & & & Lips & $\begin{array}{c}\text { Thin closed lips } \\
\text { (F: lips; M: moustache) }\end{array}$ \\
\hline
\end{tabular}

\section{E. The Final Design of Product}

The final design of product is the proposed virtual design of educative doll which was developed based on the result in Table VI. Fig. 4 describes this proposal of educative doll design.

The mapping process of product concept in Table VI is $32.5 \mathrm{~cm}$ height and $10.5 \mathrm{~cm}$ diameter determined to provide doll design that practical, practical. One motive in center of the top and batik pattern was the pattern of the doll clothes to attract consumer's attention. Programmed VR is determined to provide a source of sound in doll technology to sing a song. Velboa as the outer fabric material to prevent outside looks of the doll smooth and comfortable. The color Red R:252, R: 95, B:78, Light Yellow R: 252, G:241, B:177 represent doll color components with the color that easy to clean when dirty. Dacron is used to fill inside material of the doll as for build a comfortable feeling while consumer holds the doll. To provide attractive shape and unique design, represent by 
collaborated head section and accessories. There is hair tied, round face, round eyes, L shape nose, and thin closed lips. Fig. 4 also shows that the unique design supported by the doll looks similar to one of the Indonesian folk story, Gatot Kaca.

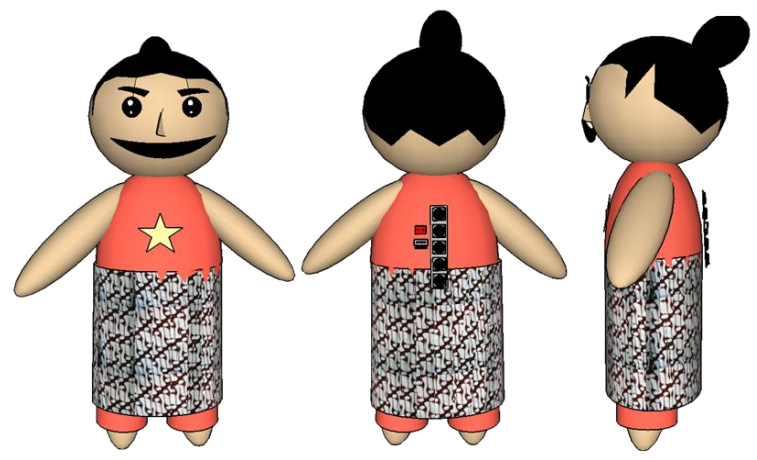

Fig. 4. The proposed design of educative doll.

\section{F. Validity Test}

Verification of doll design using marginal homogeneity test with 5\% significance level. The result can be seen in the table below (see Table VII).

TABLE VII: TEST OF HOMOGENEITY RESULT

\begin{tabular}{|c|c|}
\hline Kansei words & Asymp. Sig. (2-tailed) \\
\hline Practical & 0.101 \\
\hline Attractive & 0.666 \\
\hline Modern & 0.299 \\
\hline Soft & 0.170 \\
\hline Clean & 0.317 \\
\hline Smooth & 0.070 \\
\hline Unique & 0.116 \\
\hline
\end{tabular}

Hypothesis:

H0: There is no significance different between customer's requirement and proposed doll design.

H1: There is significance different between customer's requirement and proposed doll design.

The result shows that the null hypothesis is accepted for homogeneity of consumer's preferences. It shows by the Asymp. Sig. score all of the Kansei words $>0.05$. Thus, proposed doll design suitable for the customer needs.

\section{CONCLUSION}

Based on the result and discussion that had been described above, it can be concluded that:

1) Attribute of proposed doll design are practical, attractive, modern, smooth, clean, smooth and unique.

2) Design of doll design is with $32.5 \mathrm{~cm}$ of height and 10.5 $\mathrm{cm}$ of diameters. The most attractive pattern combination is one motif for top and motif batik pattern for the bottom. Modern doll design supported by programming user can input the command from buttons or voice command. Velboa fabric is used to represent the smoothness of proposed doll design. Clean intended by light yellow color R: 252 G: 241 B: 177, red R: 252 G: 95 B: 78. For soft design specification, proposed doll present dacron to be inside the material. Then, unique design represented by human doll with hair tied, round face, round eyes, L shape nose and thin closed lips.

3) The proposed design is valid to satisfy the customer requirement at $5 \%$ of significance level.

\section{ACKNOWLEDGMENT}

The researchers would like to appreciate upon the support of Directorate of the Student (Direktorat Kemahasiswaan) of Islamic University of Indonesia.

\section{REFERENCES}

[1] J. Forshee, "Culture and customs of Indonesia," Ebook, vol. 231, 2006.

[1] Y. Muldjaji, The Folk Underground Music as Culture Revivalism: Mixing the Sundanese Traditional Musical Instruments and Underground Music as the Struggle for Culture Sovereignty, Bandung: Universitas Padjajaran, 2014.

[2] Depdiknas, Standar Isi Mata Pelajaran SBK Tingkat Sekolah Dasar, Jakarta: Depdiknas, 2006.

[3] I. B. Simatupang, Faktor-Faktor Penyebab Kurangnya Minat Peserta Didik Kelas XI terhadap Lagu Daerah di SMK YPE Sawunggalih Kutoarjo, Yogyakarta: Universitas Negeri Yogyakarta, 2015.

[4] H. Y. Hon and X. Lin-Siegler, "How learning about scientists" struggles influences students' interest and learning in physics," Journal of Educational Psychology, vol. 104, no. 2, pp. 469-484, 2012.

[5] M. M. Keller, K. Neumann, and H. E. Fischer, "Enthusiastic teaching and its impact on students' interest and self-concept : An investigation of German physics classrooms," pp. 121-136, 2008.

[6] M. S. J. Hamzah et al., "Development of interaction scenarios based on pre-school curriculum in robotic intervention for children with autism," Procedia Computer Science, pp. 214-221, 2014.

[7] R. L. Yussof et al., "Affective engineering of background colour in digital storytelling for remedial students," Procedia - Social and Behavioral Sciences, vol. 68, pp. 202-212, 2012.

[8] A. A. Aziz et al., "Autistic children's kansei responses towards humanoid-robot as teaching mediator," Procedia Computer Science, pp. 488-493, 2015.

[9] Z. Yilmazer and H. Keklikci, "The effects of teaching geometry on the academic achievement by using puppet method," Procedia - Social and Behavioral Sciences, vol. 191, pp. 2355-2358, 2015.

[10] K. Reid-Searl et al., "Puppets in an acute paediatric unit: Nurse's experiences," Collegian, vol. 24, no. 5, pp. 441-447, 2017.

[11] F. Tegge, "The lexical coverage of popular songs in English language teaching," System, vol. 67, pp. 87-98, 2017.

[12] H. Soewardi and D. P. Rahmawati, "Educative toy design for deaf children to stimulate the fine motor skills growth," in Proc. the $3^{\text {rd }}$ Bali International Seminar on Science and Technology (BISSTECH), pp. 13-18. 2015.

[13] Widyastuti et al., "Kansei board game design of integral number arithmetic operation for elementary school," in Proc. The $2^{\text {nd }}$ Bali International Seminar on Science and Technology (BISSTECH), 2014.

[14] M. Nagamachi and A. M. Lokman, Innovation for Kansei/Affective Engineering, New York: CRC Press, 2010.

[15] Y. Matsubara and M. Nagamachi, "Hybrid kansei engineering system and design support," International Journal of Industrial Ergonomics, vol. 19, no. 2, pp. 81-92, 1997.

[16] S. Schütte, Engineering Emotional Values in Product Design - Kansei Engineering in Development. Engineering, Linköping: Linköpings Universitet, 2005.

[17] M. Nagamachi, "Kansei engineering: A new ergonomic consumer-oriented technology for product development," International Journal of Industrial Ergonomics, vol. 15, no. 1, pp. 3-11, 1995

[18] M. Nagamachi and A. M. Lokman, Innovations of Kansei Engineering, CRC Press, 2011.

[19] S. Chanyachatchawan et al., "A linguistic representation based approach to modelling Kansei data and its application to consumer-oriented evaluation of traditional products," Knowledge-Based Systems, 2017.

[20] J.-R. Chou, "Applying fuzzy linguistic preferences to kansei evaluation," in Proc. International Conference on Kansei Engineering and Emotion Research, vol. 11, 2014.

[21] R. E. Walpole and R. H. Myers, Ilmu Peluang dan Statistika untuk Insinyur dan Ilmuwan, Edisi ke 4, Institut Teknologi Bandung, 1995. 
[22] V. Kimmo and P. Simmo, "Estimation of realibility: a better alternative for Cronbach's alpha," Departement Mathemathics and Statistic University of Helshinki, Finland, 2006.

[23] C. Zheng et al., "Effects of coal properties on ventilation air leakage into methane gas drainage boreholes: Application of the orthogonal design," Journal of Natural Gas Science and Engineering, vol. 45, pp. 88-95, 2017.

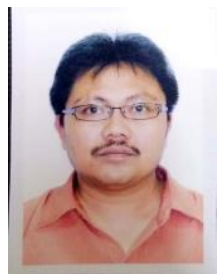

Hartomo Soewardi is a senior lecturer of the Industrial Engineering Department, Faculty of Industrial Technology, Islamic University of Indonesia, Yogyakarta, Indonesia. He was born in Banjarnegara on October 8, 1968. Currently he is a PhD in engineering design and manufacture. His teaching and research interest are industrial ergonomic design, product design, management and quality design.

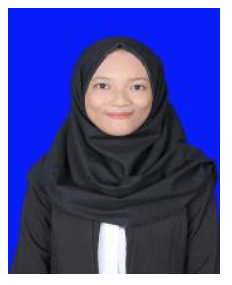

Siti Bariroh Maulidyawati received the bachelor degree in Industrial Engineering from Islamic University of Indonesia in 2018. From 2015-2017 she was an assistant of Ergonomics Laboratory. Her research interest are ergonomic design, occupational safety and health and human factor engineering. She was born in Yogyakarta, August 12, 1995. 